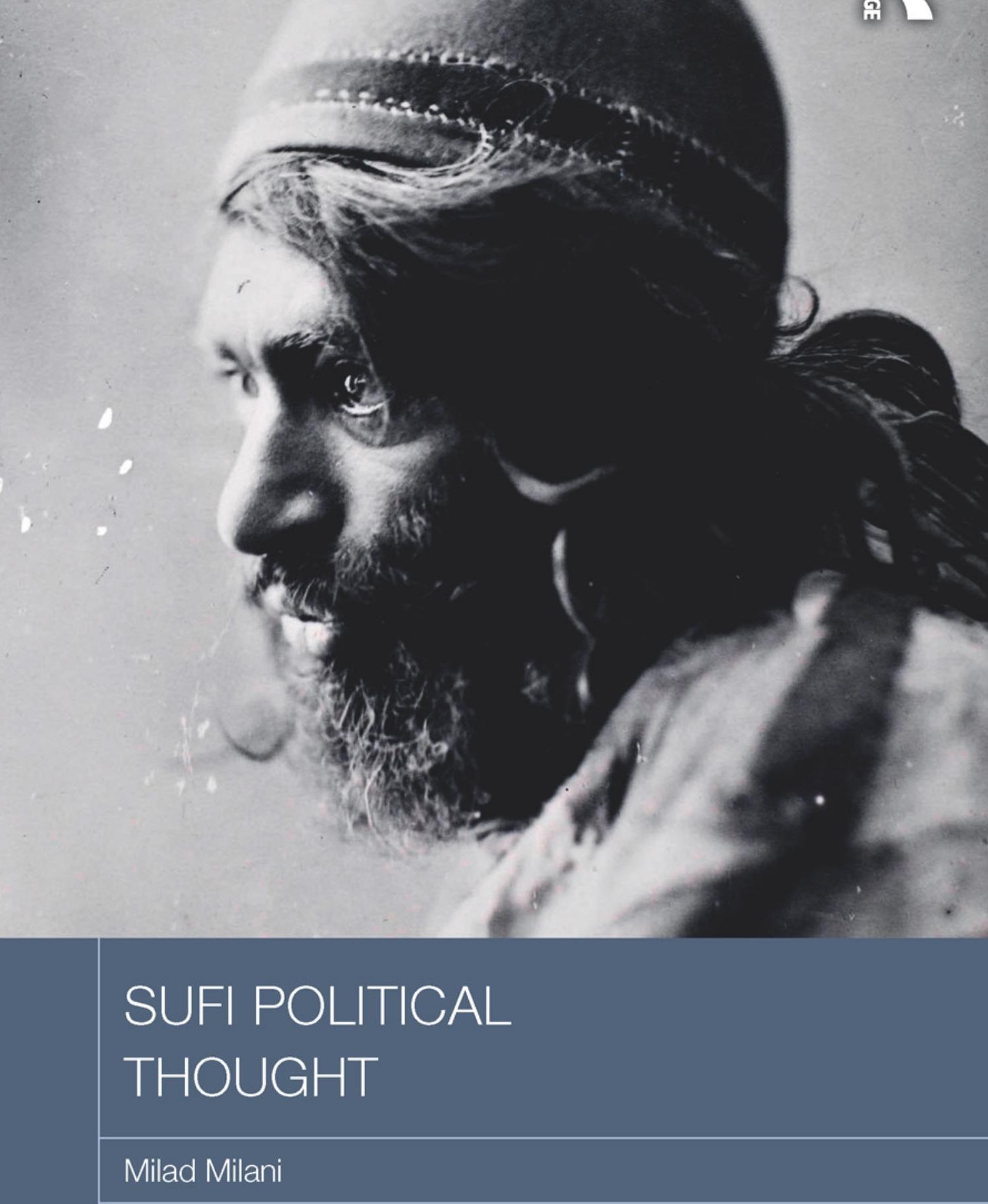




\section{Sufi Political Thought}

Sufism is generally perceived as being spiritually focused and about the development of the self. However, Sufi orders have been involved historically as important civic and political actors in the Muslim world, having participated extensively in inter-faith dialogue and political challenges to religious orthodoxy. This book presents a comprehensive overview of the Sufi political tradition, both historically and in its present form. It outlines how Sufi thought has developed, examines how Sufism has been presented both by scholars and by Sufis themselves, and considers Sufis' active political roles. It argues that Sufis - frequently well educated, well travelled and imaginative - have been well placed to engage with other faiths and absorb their ideas into Islam; but that they have also been, because they understand other faiths, well placed to understand the distinctiveness of Islam, and thereby act as the guardians of Islam's core ideas and values.

Milad Milani is Lecturer in the School of Humanities and Communication Arts at the University of Western Sydney, Australia. 


\section{Routledge Religion in Contemporary Asia Series}

\section{Series Editor}

Bryan S. Turner

Professor at the City University of New York and Director of the Centre for Religion and Society at the University of Western Sydney

\section{State Management of Religion in Indonesia} Myengkyo Seo

2. Religious Pluralism, State and Society in Asia Edited by Chiara Formichi

\section{Thailand's International Meditation Centers}

Tourism and the Global Commodification of Religious Practices Brooke Schedneck

\section{Digital Culture and Religion in Asia}

Sam Han and Kamaludeen Mohamed Nasir

5. Being Catholic in the Contemporary Philippines

Jayeel Serrano Cornelio

6. Catholics and Everyday Life in Macau

Changing Meanings of Religiosity, Morality and Civility

Chen Hon Fai

\section{Sufi Political Thought}

Milad Milani 


\section{Sufi Political Thought}

Milad Milani

Routledge

命 Taylor \& Francis Group

LONDON AND NEW YORK 
First published 2018

by Routledge

2 Park Square, Milton Park, Abingdon, Oxon OX14 4RN

and by Routledge

711 Third Avenue, New York, NY 10017

Routledge is an imprint of the Taylor \& Francis Group, an informa business

(C) 2018 Milad Milani

The right of Milad Milani to be identified as author of this work has been asserted by him in accordance with sections 77 and 78 of the Copyright, Designs and Patents Act 1988.

All rights reserved. No part of this book may be reprinted or reproduced or utilised in any form or by any electronic, mechanical, or other means, now known or hereafter invented, including photocopying and recording, or in any information storage or retrieval system, without permission in writing from the publishers.

Trademark notice: Product or corporate names may be trademarks or registered trademarks, and are used only for identification and explanation without intent to infringe.

British Library Cataloguing-in-Publication Data

A catalogue record for this book is available from the British Library

Library of Congress Cataloging-in-Publication Data

Names: Milani, Milad, author.

Title: Sufi political thought / Milad Milani.

Description: New York, NY : Routledge, [2017] | Includes bibliographical references and index.

Identifiers: LCCN 2017023114| ISBN 9781138787643 (hbk) | ISBN 9781315766294 (ebk)

Subjects: LCSH: Sufism--Political aspects. | Islam and politics.

Classification: LCC BP188.6 .M55 2017 | DDC 320.55/7--dc23

LC record available at https://lccn.loc.gov/2017023114

ISBN: 978-1-138-78764-3 (hbk)

ISBN: 978-1-315-76629-4 (ebk)

Typeset in Times New Roman

by Sunrise Setting Ltd, Brixham, UK 
For my parents, who sacrificed their world for mine. 


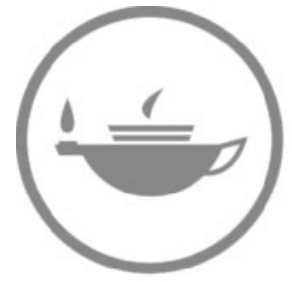

Taylor \& Francis Taylor \& Francis Group http://taylorandfrancis.com 


\section{Contents}

Foreword

ix

Acknowledgements

1 Introduction: understanding Sufism as Islam and politics 1

2 A framework for the study of Sufi political thought 4

3 Following the conceptual thread: Sufism as an experience of Asia 21

4 The open civilisation and the fundamentals of religion 38

5 Political Sufism and Sufi political interventions 64

6 A tale of two saviours: the Sufi contestation for power in medieval Islam

7 Sufism and the politics of 'Jesus'

8 Sufi politics in contemporary global society 116

9 The subtle body and the experience of politics in the human

10 Conclusion: reflections on Sufi activity in civic society today 146

Index 


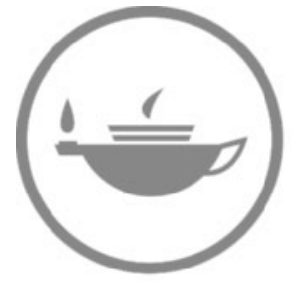

Taylor \& Francis Taylor \& Francis Group http://taylorandfrancis.com 


\section{Foreword}

Sufism has, in the West, been treated as primarily the leading branch of Islamic mysticism and hence characterised by its a-political, esoteric, and passive character. For example, the German sociologist Max Weber, whose work continues to dominate much of the sociological study of religion, described Sufism in terms of its 'passionate devotion', its cultivation of ecstasy, and its 'joyous lyricism' in his book The Sociology of Religion (1922). He thought that, because of its 'irrational and extraordinary character', Sufism did not produce a methodical control over the life world. In that regard, it was unlike the asceticism that was typical of the Protestant sects. While noting the missionary influence of popular Sufism in the global diffusion of Islam, Weber nowhere connects Sufism with politics or the state. Sufism spread, not as a warrior religion in Weber's terms, but as a network of saints and their orders or tariqahs.

Against this background, Milad Milani's encyclopaedic study of the origins, development, and continuity of Sufism is a challenge to many taken-for-granted assumptions that persist in contemporary scholarship. Sufi Political Thought is, however, not only in confrontation with conventional sociological interpretations, but it is also a challenge to the orthodox Sunni interpretation of Sufism as a sectarian deviation from the mainstream. For Milani, there is no stationary, ideal, puritanical, or continuous 'Islam'. Rather, Islam is an open tradition within which Sufism has been the major conduit of cultural exchange between religion and its external environment. The heterogeneity and complexity of Sufism is not a deviation from Islam but it is rather a living, dynamic, and fruitful engagement with other cultures and traditions, especially Christianity, from an Islamic standpoint. Consequently, Sufism represents the cosmopolitan, urbane, and outward-looking face of Islamic tradition(s). It has been open to the outside world throughout its existence. One major influence was, of course, from Persia, but Milani sees Sufism as essentially Islam in and through Asia. However, Sufism has drawn from many sources including, and especially, Christian mysticism and monasticism, giving a special place in its theology for Jesus as the perfect Sufi. In addition, Sufism has a tradition of martyrs who, like their Christian counter-parts, are witnesses to the working of the divine in human history.

As an intermediary between the world of Islam and the external world, Sufism has continuously mediated the religious and the political, while never allowing 
that dialectic to unfold into religious withdrawal or political dominance. Consequently, Sufis had to constantly negotiate a role between different states and different cultures as part of its external framework, and to negotiate a relationship with other Islamic traditions. In these diverse encounters they developed a politics of knowledge (what is authentic? What is true?) and a politics of religion (what is valid? What is authoritative?). Politics could never be avoided.

In modern times, Muslims, faced with the challenge of western secularism, have, perhaps unsurprisingly, constructed an authentic, puritan, ideal Islam that has sought to close itself off from both external cultural and religious forces. Milani thus understands the Islamic world as caught in a struggle between an exclusive and narrow puritanism promoting a selective, integrated, and idealistic view of Islamic history and an inclusive, evolving, and dynamic Islam through the medium of Sufi spirituality.

In the history of Islam, the Sufi brotherhoods played a major role in the spread of Sufism as a popular religion. Thus, Marshall G.S. Hodgson, perhaps the greatest western historian of Islam, noted the importance of the cult of dead Sufi saints and their tombs in his work The Venture of Islam (1974), whose human qualities and sympathies offered a more compassionate message than the austere doctrine of the remoteness of the Oneness of God.

There is a widespread view that the influence of Sufism has declined over time. Hodgson noted that as early as the eighteenth century the Sufi tariqahs had become burdened with the weight of 'endowed property and popular superstition'. Milani, through case studies of spiritual leaders, shows the ongoing reach and influence of modern tariqahs, especially in the West where they became popular in the twentieth century. A key figure was Hazrat Inayat Khan (d. 1927) who founded Universal Sufism to promote spirituality as the unity of all religions. Meher Baba (d. 1969) founded the American order of Sufism Reoriented. Apart from these individual figures, various Sufi orders have been successfully transplanted such as Naqshbandis, Chishtis, Qadiris, Mevlevs, Alawis, Shadhilis, and Tijanis.

Sufi Political Thought will bring about an important reinterpretation of Sufism not as a passive spirituality of mystics. By demonstrating the continuous engagement of Sufis with the political, he has established a new research agenda. The volume will do much to reshape our understanding of the broad scope of Muslim religious experience over the centuries and across the many branches of Islam. 


\section{Acknowledgements}

This book is a continuation of my exploration of Sufism as political agency and device. My intention in writing this book is for it to assist those interested in considering Sufism as part of the wider story of Islam and Muslim interaction with other religious worlds, particularly the Christian.

Initial thanks extend to Bryan Turner, who graciously invited me to consider writing a second book on Sufism, and for offering to give it a home in his series with Routledge. More than this, I am indebted to Bryan for his uncompromising study of Islam, which encouraged me to write with greater candour and reflexivity about the topic.

My extended gratitude is offered to the wonderful people at Routledge for their hard work, and for having patiently awaited the submission of the draft manuscript. I thank: Peter Sowden, Lucy McClune, Laura Briskman, Sarah Gore, Rebecca McPhee, and all involved in the editorial and production process.

In the course of writing this book I have had frequent discussions with two colleagues in particular, with whom I share a great passion for scholarly research and intellectual exploration. I would like to acknowledge Joshua Roose and Vassilios Adrahtas. I am grateful to their intellectual contribution, in the form of problems, questions, and challenges, to the writing of this book and in considering Islamic scholarship at the cutting edge.

I cannot say that mere thanks are enough to show my appreciation to the very dear people who agreed to the arduous task of reading drafts of this manuscript. I am indebted to them for their invaluable feedback, comments, and corrections, which helped to produce a coherent and legible work. My sincere thanks to the love of my life, Natasha Maiolo, my father-in-law, Raphael Maiolo, and to my esteemed colleague, Jason Ensor. 


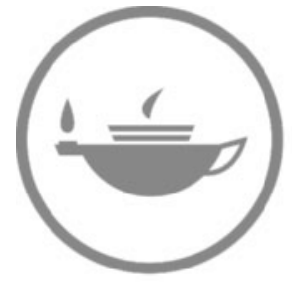

Taylor \& Francis Taylor \& Francis Group http://taylorandfrancis.com 


\section{Introduction}

\section{Understanding Sufism as Islam and politics}

'What is Sufism'? Phenomenologically, Sufism is, like most religious and spiritual traditions, both a heuristic process and a method in that it encompasses both the journey towards something and the way to achieve that end. In the case of Sufism, however, the tradition provides a restricted framework within which the acolyte can spiritually explore and study the experience of Islam. Operating from within this parameter, Sufism becomes a 'Muslim hermeneutic' in that it additionally offers its own method and theory of interpretation of the Islamic canon that is characteristically mystical.

While the origins of Sufism remain a point of historical contention, and more suitably a matter of historiography, it can be defined as a form of interior religion practiced by an unknown number of Muslims around the world. Since later Sufi chroniclers compiled the tradition retrospectively, it is difficult to ascertain a comprehensive answer to what Sufism is and how it is to be understood historically. Broad studies of Sufism have generally held Sufism as being intrinsic to early Islamic practice, and have assumed it to literally be there from the beginning, often held to have originated with the practices of Muhammad. Historicisations of Sufism, however, have tended to restrict Sufism as a new development in the medieval period and one to have specifically originated in the middle of the ninth century. Yet, as hinted above, Sufism is a mode, among many others, of interpreting Islam from the inside, facilitated by its own 'reading' of the past. It is, therefore, both a historical and phenomenological concern which will be explored in the pursuing chapters of this book.

The problem of writing a history of Sufism is a definitional one, which results in a debate about origins. This aside, the Sufi tradition is not conventionally impervious to documentation, nor has scholarship lacking want in reconstructing historical Sufism (cf., Knysh, 2010; Green, 2012). To follow the historical trail, Sufism initially emerges in a gradual fashion in the backdrop of the process of conversion to Islam among non-Arab peoples of the conquered territories, predominantly in the Iran and Iraq regions. Based on medieval biographical materials, there is evidence to suggest that Sufism grew out of a need for these converts (from Jewish, Christian, Zoroastrian ancestry) to adapt their understanding of Islam to aspects of their own heritage, and as part of the process of defining their own identity as clients to the establishing Arab Muslim empire (Bulliet, 1994). 


\section{Introduction}

It is, therefore, arguable that Sufism does not have a singular point of origin in either a specific event or a central figurehead, unlike Islam which traditionally has its origins in the person and revelation of Muhammad. This is not to say, however, that Muhammad is not the phenomenological foundation of Sufi understanding. Herein lies a subtler point about the hermeneutics of history that needs to be contextualised in its proper period and framework. Whatever non-Islamic religious elements have been appropriated by the Sufis historically, these have not been without a foundational basis in the Qur'an. The emergence of Sufism is better described as the result of several processes that relate to regional typography. First, on a micro-level, its rise to prominence can be considered as being closely connected to the success of its innovative interpretation of religion and adaptation of Islamic religious practice to regional customs as found across the medieval Muslim world. Secondly, on a macro-level, the rise of Sufism is concurrent with the shift from an Arab-centred religious dynasty to a universal empire increasingly defined by its vast majority (and growing population) of non-Arab Muslims. The third step of this process broadly relates to the delineation of a mystical tradition and associated cultural production (cf., Milani, 2012a; 2012b).

All of this is to pose a key question: what is political about Sufism? Or how is being a Sufi political? Sufism represents a version of the Islamic past; it is an interpretation of Islam peculiar to mystical reading of the Islamic canon. Sufis are political by participating in the perpetuation of their Islamic narrative. Islam is first historically manifest as a polity, embodying a synthesised religious and political ideology. Yet, what remained dormant is what Muhammad Taha (1909-1985) alleged as the first message of Islam. This came to light in the works of Montgomery Watt as distinct periodic stages of Muhammad's career in Mecca and Medina, which indicate a juxtaposed, though not disassociated, religiosity. Sufism can be tied into this theme as an early Islamic method of extracting what might be deemed to be a spiritual reading of the Qur'an. Sufis thrived during a time that was simultaneously attuned to the growth of jurisprudence. Notable Sufi figures were educated Muslims who navigated the religious terrain disseminating the mysteries of Islam without opposing the Law. What makes Sufism political is the role it has aspired to play in shaping Muslim polity. Being a Sufi becomes political when certain interpretations of religion challenge the mainstream. What will become clear in this book is the varied nature of Sufi political thought from an examination of several samples from history and contemporary Sufism.

As a subject of study, Sufism is nuanced and definitionally complex. A fact that is also representative of the reality of its tradition. Therefore, in writing this book, certain sensitivities are taken into consideration. First, that its approach should be both discerning to scholarship and representative of the tradition under scrutiny. There is no point in speaking about Sufism without taking into consideration the value of the living tradition to which it is beholden and what this means to those that are representative of its praxis.

As such, the methods utilised in this book are derived from the discipline of studies in religion, which includes the history of religions and comparative religion, and which is polymethodic and multidisciplinary. This approach allows for 
the flexibility to examine and discuss Sufism both as a phenomenon of historical and human enquiry. In this task the book engages both the historical and sociological disciplines, but through the lens of its primary focus, giving special attention to often glossed-over religious subject matter. The signalled approach will also assist in appreciating the ways in which religion comes to be understood, processed, and embodied as a living reality in the consciousness of the agent, which then has its subsequent impact upon the social and political spheres. Second, that the resulting research should provide something familiar but previously unrecognised; known, but not understood; same, but different. This second qualification should not only contribute, and relate, to more than one branch of knowledge (that is, it must be interdisciplinary), but it should also carry a component that goes beyond disciplinary boundaries to create a holistic approach (transdisciplinary). In doing so, the aim is not just to cross disciplinary boundaries, but also to think through the subject itself in order to create new conceptual, theoretical, methodological, and interpretative innovations that bring together newly formed understandings not limited by discipline-specific approaches that seek to address a common problem from varying angles.

The first two chapters of this book are designed to provide the reader with a background to the complications of typecasting Sufism and locating it within academic discourse. They are, therefore, stand-alone chapters that do not necessarily spill over into the rest of the book and, as such, are paradigmatic of the intention of the book rather than prescriptive as to its content. The first chapter aims to cut through conceptual misperceptions and problems relating to the typology of Sufism. The second chapter examines the concerns around discussing the subject of Sufism in academic context. Both are necessary for the commencement of setting up a framework for the study of Sufi political thought. The middle four chapters are historiographical in nature, focused on the meeting point of religion and politics in the Islamic history. The last two chapters are approaches from historical anthropology, which expound on charismatic leadership and the experience of religion in the body.

\section{References}

Bulliet, R. (1994). Islam: the view from the edge. New York: Columbia University Press.

Green, N. (2012). Sufism: a global history. Oxford: Blackwell Publishing.

Knysh, A. (2010). Islamic mysticism: a short history. 2nd ed. Leiden: Brill.

Milani, M. (2012a). The cultural products of global Sufism. In: C. Cusack and A. Norman, eds., Handbook of new religions and cultural production. 1st ed. Leiden: Brill, pp. 659-680.

Milani, M. (2012b). The cultural repository of Persian Sufism: medieval chivalry and mysticism in Iran. In: S. Hathaway and D. Kim, eds., Intercultural exchange in the early medieval Mediterranean. 1st ed. London: Continuum, pp. 63-83. 


\section{Introduction}

Bulliet, R. (1994). Islam: the view from the edge. New York: Columbia University Press. Green, N. (2012). Sufism: a global history. Oxford: Blackwell Publishing.

Knysh, A. (2010). Islamic mysticism: a short history. 2nd ed. Leiden: Brill.

Milani, M. (2012a). The cultural products of global Sufism. In: C. Cusack and A. Norman , eds., Handbook of new religions and cultural production. 1st ed. Leiden: Brill, pp. 659-680.

Milani, M. (2012b). The cultural repository of Persian Sufism: medieval chivalry and mysticism in Iran. In: S. Hathaway and D. Kim , eds., Intercultural exchange in the early medieval Mediterranean. 1st ed. London: Continuum, pp. 63-83.

\section{A framework for the study of Sufi political thought}

Ahmed, S. (2016). What is Islam? The importance of being Islamic. Oxford: Princeton University Press.

Bourdieu, P. (1984). Distinction. London: Routledge.

Curry, J.J. , and Ohlander, E.S. , eds. (2012). Sufism and society: arrangements of the mystical in the Muslim world, 1200-1800 (Routledge Sufi series, Vol. 12). 1st ed. Abingdon: Routledge. Foucault, M. (1996). What our present is? In: S. Lotringer, ed., Foucault live: collected interviews, 1961-1984. New York: Semiotext(e), pp. 407-415.

Genn, C. (2007). The development of a modern western Sufism. In: J.D. Howell and M. van Bruinessen , eds., Sufism and the 'modern' in Islam. 1st ed. London: I.B. Tauris, pp. 257-277. Genn, C. (2013). What's in a Name Changes and Challenges in One Hundred Years of Inayat Khan's (Inayati) Universal Sufism. Journal for the Academic Study of Religion, 26(1), pp. 7-28. Goodman, L.E. (2003). Islamic humanism. Oxford: Oxford University Press.

Green, N. (2012). Sufism: a global history. Oxford: Blackwell Publishing.

Howell, J.D. , and van Bruinessen, M. , eds. (2007). Sufism and the 'modern' in Islam. London: I.B. Tauris.

Knysh, A. (2010). Islamic mysticism: a short history. 2nd ed. Leiden: Brill.

Malik, J. , and Hinnells, J. , eds. (2006). Sufism in the West. London: Routledge.

Milani, M. (2014). Sufism in the secret history of Persia. 2nd ed. Abingdon: Routledge.

Milani, M. , and Possamai, A. (2013). The Nimatullahiya and Naqshbandiya: a Case Study of Two Traditional Sufi Orders and Resistance to the McDonaldisation of Spirituality. Journal for the Academic Study of Religion, 26(1), pp. 51-57.

Sedgwick, M. (2017). Western Sufism: from the Abbasids to the new age. Oxford: Oxford University Press.

Thompson, P. (2008). Field. In: M. Grenfell , ed., Pierre Bourdieu: key concepts. Durham: Acumen, pp. 67-84.

Turner, B. , and Nasir, K.M. , eds. (2013). Sociology of Islam: collected essays of Bryan S. Turner. Burlington, VT: Ashgate.

\section{Following the conceptual thread}

Anklesaria, B.T. (1956). Bundahishn. Bombay.

Ansari, A. (2012). The politics of nationalism in modern Iran. Cambridge: Cambridge University Press.

Boyce, M. (1975). A history of Zoroastrianism. Leiden: Brill.

Boyce, M. (1979). Zoroastrians: their religious beliefs and practices. London: Routledge.

Bulliet, R. (1994). Islam: the view from the edge. New York: Columbia University Press.

Bulliet, R. (2009). Cotton, climate, and camels in early Islamic Iran: a moment in world history. New York: Columbia University Press.

Choueiri, Y.M. , ed. (2005). A companion to the history of the Middle East. Malden, MA:

Blackwell Publishing. 
Cooper, A.S. (2016). The fall of heaven: the Pahlavis and the final days of imperial Iran. New York: Henry Holt and Company.

Corbin, H. (1971-1972). En Islam Iranien, aspects spirituels e philosophiques. Paris: Gallimard. Corbin, H. ([1964] 1993). History of Islamic philosophy. London: Kegan Paul.

Curry, J.J. , and Ohlander, E.S. , eds. (2012). Sufism and society: arrangements of the mystical in the Muslim world, 1200-1800 (Routledge Sufi series, Vol. 12). 1st ed. Abingdon: Routledge. Foucault, M. (2002). The archaeology of knowledge. A.M. Sheridan Smith, trans. New York: Routledge.

Green, N. (2012). Sufism: a global history. Malden, MA: Wiley-Blackwell.

Hamzehee, R. (1991). Land of revolutions: a historical and typological study of Iranian social movements. Göttingen: Edition RE.

Hinnells, J. (1974). The Iranian Background of Mithraic Iconography. Acta Iranica, 1, pp. 271-284.

Hodgson, M.G. (1974). The venture of Islam: conscience and history in a world civilization. Chicago, IL: University of Chicago Press.

Hughes, A. (2007). Situating Islam: the past and future of an academic discipline. London: Equinox Publishing.

Hughes, A. (2012). Theorising Islam: disciplinary deconstruction and reconstruction. Bristol, CT: Equinox Publishing.

Jensen, L. (2005). Unsettling Australia: readings in Australian cultural history. New Delhi: Atlantic Publishers and Distributors.

Knysh, A. (1994). Ibn Arabi in the later Islamic tradition: the making of a polemical image in medieval Islam. Albany, NY: State University of New York.

Knysh, A. (2005). Historiography of Sufi studies in the West. In: Y.M. Choueiri, ed., A

companion to the history of the Middle East. 1st ed. Malden, MA: Blackwell Publishing, pp. 106-131.

Knysh, A. (2010). Islamic mysticism: a short history. 2nd ed. Leiden: Brill.

Lewisohn, L. (2006). Persian Sufism in the contemporary West: reflections on the Ni'matu'llahi diaspora. In: J. Malik and J. Hinnells, eds., Sufism in the West. London: Routledge, pp. 49-70. Melikian-Chirvani, A.S. (1990). From the Royal Boat to the Beggar's Bowl. Islamic Art, 4, pp. 3-111.

Melikian-Chirvani, A.S. (1992). The wine bull and the Magian master. In: P. Gignoux , ed., Recurrent patterns in Iranian religions: from Mazdaism to Sufism (Special Issue of Studia Iranica, Vol. 11). Paris: Association pour l'Avancement des Études Iraniennes, pp. 101-133. Milani, M. (2014). Sufism in the secret history of Persia. Abingdon: Routledge.

Milani, M. (2016). Sufism, Spirituality and Consumerism: The Case Study of the Nimatullahiya and Naqshbandiya Sufi Orders in Australia. Contemporary Islam: Dynamics of Muslim Life, 10(1), pp. 67-85.

Mirrazavi, F. (2013). The Removing of Hijab in Iran. Iran Review. [Online] Available at: www.iranreview.org/content/Documents/The-Removing-of-Hijab-in-Iran.htm [Accessed 21 Mar 2015 ].

Nurbakhsh, J. (2000). Sufi symbolism: the Nurbakhsh encyclopaedia of Sufi terminology. London: Khaniqahi Nimatullahi Publications.

Pourshariati, P. (2008). Decline and fall of the Sasanian Empire: the Sasanian-Parthian confederacy and the Arab conquest of Iran. London: I.B. Tauris.

Ridgeon, L. (2010). Morals and mysticism in Persian Sufism: a history of Sufi-Futuwwat in Iran (Routledge Sufi Series, 10). Abingdon: Routledge.

Rogers, E.M. (1962). Diffusion of innovations. 1st ed. New York: Free Press of Glencoe. Sanson, B. (1985). Aborigines, anthropologists and leviathan. In: N. Dyck, ed., Indigenous peoples and the nation-state: fourth world politics in Canada, Australia and Norway (Social and Economic Papers, No. 14). St. John's: Institute of Social and Economic Research, Memorial University of Newfoundland, pp. 67-94.

Sears, L.J. (2000). Intellectuals, theosophy, and failed narratives of the nation in late colonial Java. In: H. Schwarz and S. Ray , eds., A companion to postcolonial studies. Malden, MA: Blackwell Publishing, pp. 333-359.

Trompf, G.W. (1989). Macrohistory and Acculturation: Between Myth and History in Modern Melanesian Adjustments and Ancient Gnosticism. Comparative Studies in Society and History, 31(4), pp. 621-648. 
Van Bruinessen, M. (1998). Sufism and the Sufi Orders in Indonesia. Die Welt des Islam, 38(2), pp. 192-219.

Weaver, J. (2000). Indigenousness and indigeneity. In: H. Schwarz and S. Ray, eds., A companion to postcolonial studies. Malden, MA: Blackwell Publishing, pp. 221-235.

Zaehner, R.C. ([1960] 1994). Hindu and Muslim mysticism. Oxford: Oneworld Publications.

\section{The open civilisation and the fundamentals of religion}

Al-Rasheed, M. (2002). A history of Saudi Arabia. Cambridge: Cambridge University Press. Amara, M. , ed. (1989). Kitab al-Amwal (of Abu Ubayd al-Kasim b. Sallam). Beirut: Dar alShuruq.

Andrae, T. (c. 1987). In the garden of myrtles: studies in early Islamic mysticism. B. Sharpe, trans. Albany, NY: State University of New York Press.

Asfaruddin, A. (2007). The first Muslims: history and memory. London: Oneworld Publications. Bellah, R.N. (2005). Civil Religion in America. Daedalus, 134(4), pp. 40-55.

Böwering, G. (2008). Recent research on the construction of the Qur'an. In: G.S. Reynolds , ed., The Qur'an and its historical context. London: Routledge, pp. 70-87.

Böwering, G. (2011). Ayn al-Quzat Hamadani. Encyclopaedia Iranica, 3(2), pp. 140-143.

[Online] Available at: www.iranicaonline.org/articles/ayn-al-qozat-hamadani-abul-maali-

abdallah-b [Accessed 3 Jan 2016 ].

Bulliet, R. (1994). Islam: the view from the edge. New York: Columbia University Press.

Bulliet, R. (2009). Cotton, climate, and camels in early Islamic Iran: a moment in world history.

New York: Columbia University Press.

Bulliet, R. (2012). Islam: The Open Civilization. [Video] Available at:

https://youtu.be/gWqZw5QO-vA, published 4 April 2012 [Accessed 3 Mar 2016 ].

Bulliet, R. , and Voll, J. (2011). Beyond Golden Age and Decline: The Legacy of Muslim

Societies in Global Modernity. [Video] Available at: https://vimeo.com/31939385 [Accessed 3

Mar 2016 ].

Bulliet, R. , Crossley, P. , Headrick, D. , Hirsch, S. , and Johnson, L. (2015). The Earth and its peoples. 6th ed. Stamford, CT: Cengage Learning.

Bury, R.G. , trans. (1966). Plato in twelve volumes, Vol. 7. Cambridge, MA: Harvard University Press.

Collingwood, R.G. (1946). Human nature and human history. In: J. van der Dussen, ed., The idea of history. Oxford: Oxford University Press, pp. 204-231.

Cook, M. (2004). Studies in the origins of early Islamic culture and tradition. Aldershot: Ashgate.

Crone, P. , and Cook, M. (1977). Hagarism: the making of the Islamic world. Cambridge:

Cambridge University Press.

Daftary, F. (2014). Study of Shi'i Islam: history, theology and law. London: I.B. Tauris.

Delong-Bas, N.J. (2004). Wahhabi Islam: from revival and reform to global jihad. Oxford: Oxford University Press.

Ernst, C.W. (1985). From Hagiography to Martyrology: Conflicting Testimonies to a Sufi Martyr of the Delhi Sultanate. History of Religions, 24(4), pp. 308-327.

Gentile, E. (1996). The sacralization of politics in fascist Italy. K. Botsford, trans. Cambridge, MA: Harvard University Press.

Green, N. (2012). Sufism: a global history. Malden, MA: Wiley-Blackwell.

Guillaume, A. (1955). The life of Muhammad: a translation of Ibn Ishaq's sirat rasul allah.

Oxford: Oxford University Press.

Hanif, N. (2002). Biographical encyclopaedia of Sufis: Central Asia and Middle East. New Delhi: Sarup and Sons.

Hodgson, M.G. (1974). The venture of Islam: conscience and history in a world civilization.

Chicago, IL: University of Chicago Press.

Hughes, A. (2007). Situating Islam: the past and future of an academic discipline. London:

Equinox Publishing.

Hughes, A. (2012). Theorising Islam: disciplinary deconstruction and reconstruction. Bristol, CT:

Equinox Publishing. 
Hughes, A. (2015). Islam and the tyranny of authenticity: an inquiry into disciplinary apologetics and self-deception. Bristol, CT: Equinox Publishing.

Husserl, E. (1970). The crisis of European sciences and transcendental phenomenology.

Evanston, IL: Northwestern University Press.

Kansteiner, W. (2002). Finding Meaning in Memory: A Methodological Critique of Collective Memory Studies. History and Theory, 41(2), pp. 179-197.

Karsh. E. (2006). Islamic imperialism: a history. New Haven, CT: Yale University Press.

Knysh, A. (2010). Islamic mysticism: a short history. 2nd ed. Leiden: Brill.

Lings, M. (1983). Muhammad: his life based on the earliest sources. London: Islamic Texts

Society; Allen \& Unwin.

Mackie, J. (1976). Problems from Locke. Oxford: Oxford University Press.

Massignon, L. , ed. (1974). Tawasin. A.A. al-Tarjumana, trans. Berkeley, CA: Diwan Press.

Massignon, L. (1982a). The passion of al-Hallaj I. Princeton, NJ: Princeton University Press.

Massignon, L. (1982b). The passion of Hallaj: mystic and martyr of Islam, 4 vols. H. Mason, trans. Princeton, NJ: Princeton University Press.

Massignon, L. , and Gardet, L. (2012). al-Halladj. 2nd ed. In: Encyclopaedia of Islam. [Online] Available at: http://dx.doi.org.ezproxy.uws.edu.au/10.1163/1573-3912_islam_COM_0256 [Accessed 1 Feb 2016].

Milani, M. (2012). Representations of Jesus in Islamic Mysticism: Defining the 'Sufi Jesus'.

Literature and Aesthetics, 21(2), pp. 45-64.

Mojaddedi, J. (2001). The biographical tradition in Sufism: the tabaqaat genre from al-Sulamii to Jami. Richmond, Surrey: Curzon Press.

Mojaddedi, J. (2003). Hallaj, Abu'l-Mogit Hosayn. In: Encyclopaedia Iranica. [Online] New York: Columbia University Centre for Iranian Studies, 11(6), pp. 589-592. Available at:

www.iranicaonline.org/articles/hallaj-1 [Accessed 1 Feb. 2016].

Nicholson, R.A. (1994). Studies in Islamic mysticism. 7th ed. Richmond, Surrey: Curzon Press.

Pew Research Centre . (2012). The world's Muslims: unity and diversity. Washington, DC: Pew Research Centre.

Platt, K. (1985). Island Puritanism. In: E. Gellner , ed., Islamic dilemmas: reformers, nationalists and industrialization: the southern shore of the Mediterranean. Berlin: Mouton Publishers, pp.

169-186.

Pourjavadi, N. (2013). Sawanih: inspirations from the world of pure spirits: the oldest Persian

Sufi treatise on love. 2nd ed. Abingdon: Routledge.

Rodinson, M. (1966). Islam and capitalism. London: Saqi Books.

Silverstein, A.J. (2010). Islamic history: a very short introduction. Oxford: Oxford University

Press.

Turner, B. , and Nasir, K.M. , eds. (2013). The sociology of Islam: collected essays of Bryan S.

Turner. Burlington, VT: Ashgate.

Vann, B.A. (2011). Puritan Islam: the geoexpansion of the Muslim world. New York:

Prometheus Books.

Von Grunebaum , G.E. (1970). Classical Islam. London: Allen \& Unwin.

Walzer, M. (1982). The revolution of the saints: a study in the origins of radical politics.

Cambridge: Harvard University Press.

Watt, M. (1953). Muhammad at Mecca. Oxford: Oxford University Press.

Watt, M. (1956). Muhammad at Medina. Oxford: Oxford University Press.

Ziai, H. (1990). Knowledge and illumination: a study of Suhrawardi's Hikmat al-Ishraq. Atlanta,

GA: Scholars Press.

\section{Political Sufism and Sufi political interventions}

Ahdar, R. , and Aroney, N. , eds. (2010). Shari'a in the West. Oxford: Oxford University Press.

Akbarzadeh, S. (2012). The paradox political Islam. In: S. Akbarzadeh, ed., The Routledge

handbook of political Islam. New York: Routledge, pp. 1-8.

Arberry, A.J. (1983). Muslim saints and mystics episodes from the Tadhkirat al-Auliya'

("Memorial of the Saints"). 5th ed. London: Routledge and Kegan Paul. 
Bendle, M.F. (2003). Global Jihad and the Battle for the Soul of Islam. Journal for the Academic Study of Religion, 16(2), pp. 125-140.

Bruinessen, M. (1998). Sufism and the Sufi Orders in Indonesia. Die Welt des Islam, 38(2), pp. 192-219.

Bruinessen, M. (2009). Sufism, "popular" Islam and the encounter with modernity. In: M.K. Masud, A. Salvatore and M. van Bruinessen eds., Islam and modernity. Edinburgh: Edinburgh University Press, pp. 125-157.

Bulliet, R. (1994). Islam: the view from the edge. New York: Columbia University Press.

Bulliet, R. (2008). Islamic Radicals Debate: Richard Bulliet 7/15-Intelligence Squared U.S.

[Video] Available at: https://youtu.be/XROJwaRg9pM [Accessed 3 Mar 2016 ].

Bulliet, R. (2012). Islam: The Open Civilization. [Video] Available at:

https://youtu.be/gWqZw5QO-vA [Accessed 3 Mar 2016].

Crone, P. (2012). The nativist prophets of early Islamic Iran. Cambridge: Cambridge University Press.

Curry, J.J. , and Ohlander, E.S. , eds. (2012). Sufism and society: arrangements of the mystical in the Muslim world, 1200-1800 (Routledge Sufi series, Vol. 12). 1st ed. Abingdon: Routledge.

Deasy, K. (2012). The Sufis' Choice: Egypt's Political Wild Card, World Affairs Journal. [Online] Available at: www.worldaffairsjournal.org/article/sufis\%E2\%80\%99-choice-egypt\%E2\%80\%99spolitical-wild-card [Accessed 16 Feb 2014 ].

Green, N. (2012). Sufism: a global history. Malden, MA: Wiley-Blackwell.

Heck, P.L. (2007). Sufism and politics: the power of spirituality. Princeton, NJ: Markus Wiener

Publishers.

Hoffman, V.J. (1995). Sufism, mystics, and saints in modern Egypt. Columbia, SC: University of South Carolina Press.

Howell, J. (2001). Sufism and the Indonesian Islamic Revival. Journal of Asian Studies, 60(3), pp. 701-729.

Howell, J. (2014). Revitalised Sufism and the new piety movements in Islamic Southeast Asia. In: B. Turner, ed., Routledge handbook of religions in Asia. London: Routledge, pp. 276-292. Khaldun, I. (2015). The Muqaddimah. F. Rosenthal , trans., and N.J. Dawood, ed. Princeton, $\mathrm{NJ}$ : Princeton University Press.

Malik, J. , and Hinnells, J. , eds. (2006). Sufism in the West. London: Routledge.

MENA (Middle East News Agency) . (2013). Sufi Leader Calls on Egyptians to Vote in Constitution Referendum, The Cairo Post. [Online] Available at:

http://thecairopost.com/news/50190/news/sufi-leader-calls-egyptians-vote-constitutionreferendum [Accessed 1 Feb 2014 ].

Milani, M. (2014). Sufism in the secret history of Persia. Abingdon: Routledge.

Milani, M. , and Possamai, A. (2013). The Nimatullahiya and Naqshbandiya: A Case Study of Two Traditional Sufi Orders and Resistance to the McDonaldisation of Spirituality. Journal for the Academic Study of Religion, 26(1), pp. 51-57.

Milani, M. , and Possamai, A. (2015). Sufism, Spirituality and Consumerism: The Case Study of the Nimatullahiya and Naqshbandiya Sufi Orders in Australia. Contemporary Islam: Dynamics of Muslim Life, 10(1), pp. 67-85.

Pew Research Center . (2015). The Future of World Religions: Population Growth Projections, 2010-2050. Washington, DC: Pew Research Centre. [Online] Available at: www.

pewforum.org/2015/04/02/religious-projections-2010-2050/ [Accessed 2 Apr 2015 ].

Phelps, T.M. (2014). The Preacher Shaking up Turkey - From America, McClatchy-Tribune.

[Online] Available at:

www.thestar.com/news/world/2014/02/09/the_preacher_shaking_up_turkey_from_america.html [Accessed 16 Feb 2014].

Rozenhal, R.T. (2007). Islamic Sufism unbound: politics and piety in twenty-first century

Pakistan. New York: Palgrave Macmillan.

Said, I. (2013). The Union of Sufi Powers: 18 Million Sufis Vote for Constitution, The Cairo Post. [Online] Available at: http://thecairopost.com/news/60936/news/union-sufi-powers-18-millionsufis-vote-constitution [Accessed 16 Feb 2014 ].

Stenhouse, P. (2007). Islam's Trojan Horse?: Turkish Nationalism and the Nakshibendi Sufi Order. Quadrant, 51(12), pp. 11-18.

Trompf, G.W. (c. 1979). The idea of historical recurrence in Western thought: from antiquity to the Reformation. Berkeley, CA: University of California Press. 
Turner, B. , and Nasir, K.M. , eds. (2013). The sociology of Islam: collected essays of Bryan S. Turner. Burlington, VT: Ashgate.

Van den Bos, M . (2002). Mystic regimes: Sufism and the state in Iran, from the late Qajar era to the Islamic Republic. Leiden: Brill.

\section{A tale of two saviours}

Arberry, A.J. (1983). Muslim saints and mystics episodes from the Tadhkirat al-Auliya'

("Memorial of the Saints"). 5th ed. London: Routledge and Kegan Paul.

Bonner, M. (1996). Aristocratic violence and holy war: studies in the Jihad and the Arab-

Byzantine frontier. New Haven, CT: American Oriental Society.

Bourdieu, P. (1971). Intellectual field and creative project. In: M.F.D. Young, ed., Knowledge and control: new directions for the sociology of education. London: Macmillan.

Bourdieu, P. (1984). Distinction. London: Routledge.

Bourdieu, P. (2005). The social structures of the economy. Cambridge: Polity Press.

Bourdieu, P. , and Wacquant, L.J.D. (1992). An invitation to reflexive sociology. Chicago, IL:

University of Chicago Press.

Böwering, G. (1980). The mystical vision of existence in classical Islam: the Qur'ainc

hermeneutics of the Sufi Sahl at-Tustari (d. 283/896). New York: Walter De Gruyter.

Bulliet, R. (1994). Islam: the view from the edge. New York: Columbia University Press.

Cooperson, M. (2000). Classical Arabic biography: heirs of the prophets in the age of al-

Ma'mun. Cambridge: Cambridge University Press.

Cragg, K. (1984). Muhammad and the Christian. London: Longmann and Todd.

Dewald, J. (1996). The European nobility, 1400-1800. Cambridge: Cambridge University Press.

Ernst, C.W. (1985). Words of ecstasy in Sufism. Albany, NY: State University of New York

Press.

Fisal, N. , ed. (1959). Musibatname. Tehran.

Gibb, H.A.R. (1975). Islam: a historical survey. 2nd ed. Oxford: Oxford University Press.

Goddard, H. (1996). Muslim perceptions of Christianity. London: Grey Seal.

Goddard, H. (2001). Christian-Muslim relations in Nigeria and Malaysia. In: L. Ridgeon, ed.,

Islamic interpretations of Christianity. Abingdon: Routledge, pp. 231-247.

Green, N. (2012). Sufism: a global history. Malden, MA: Wiley-Blackwell.

Grenfell, M. , ed. (2008). Pierre Bourdieu: key concepts. Durham: Acumen.

Iqbal, M. (1932). Javidnama. Lahore.

Knysh, A. (2010). Islamic mysticism: a short history. 2nd ed. Leiden: Brill.

Lapidus, I.M. (2014). A history of Islamic societies. 3rd ed. New York: Cambridge University

Press.

Layder, D. (2004). Emotion in social life: the lost heart of society. London: SAGE Publications. Mason, H. (1999). Hallaj and the Baghdad school of Sufism. In: L. Lewisohn, ed., The heritage of Sufism 1. Oxford: Oneworld Publications, pp. 65-82.

Massignon, L. , ed. (1974). Tawasin. A.A. al-Tarjumana, trans. Berkeley, CA: Diwan Press.

Massignon, L. (1994). The passion of Al-Hallaj: mystic and martyr of Islam. H. Mason , ed., trans. Princeton, NJ: Princeton University Press.

Nwyia, P. (1970). Exégèse coranique et langage mystique: nouvel essai sur le lexique technique des mystiques Musulmans. Beirut: Dar el-Machreq.

Ridgeon, L. (2001). Christianity as portrayed by Jalal al-Din Rūmi. In: L. Ridgeon, ed., Islamic interpretations of Christianity. Abingdon: Routledge, pp. 99-126.

Ruthven, M. (2001). Introduction. In: L. Ridgeon, ed., Islamic interpretations of Christianity. Abingdon: Routledge, pp. xi-xx.

Schimmel, A. (1975). Mystical dimensions of Islam. Chapel Hill, NC: University of North Carolina Press.

Schimmel, A. (1985). And Muhammad is his messenger: the veneration of the prophet in Islamic piety. Chapel Hill, NC: University of North Carolina Press.

Vadet, J.C. , ed. (1962). Kitab 'ațf al-alif al-ma'luf ila'l-lam al-ma'tuf (of Daylami, Ali ibn Ahmad). Cairo. 


\section{Sufism and the politics of 'Jesus' \\ 1}

Arberry, A.J. (1983). Muslim saints and mystics episodes from the Tadhkirat al-Auliya'

("Memorial of the Saints"). 5th ed. London: Routledge and Kegan Paul.

Austin, R.W.J. (1980). The bezels of wisdom. London: The Society for Promoting Christian Knowledge Press.

Bastani-Parizi, M.E. (1998). Khaneqah: a phenomenon in the social history of Iran. In: G.W. Trompf and M. Honari , eds., Mehregan in Sydney: proceedings of the seminar in Persian studies during the Mehregan Persian Cultural Festival, Sydney, Australia 28 October-6 November 1994. Sydney: University of Sydney Printing Services, pp. 70-79.

Beeston, A.F.L. (1983). The Cambridge history of Arabic literature: Arabic literature to the end of the Umayyad period. Cambridge: Cambridge University Press.

Bornkamm, G. (1995). Jesus of Nazareth. Minneapolis, MN: Fortress Press.

Bourdieu, P. (1977). Outline of a theory of practice. Cambridge: Cambridge University Press.

Bourdieu, P. (1999). The weight of the world: social suffering in contemporary society. Stanford, CA: Stanford University Press.

Bourdieu, P. (2005). The social structures of the economy. Cambridge: Polity Press.

Bourdieu, P. , and Wacquant, L. (1999). On the Cunning of Imperialist Reason. Theory, Culture and Society, 16(1), pp. 41-58.

Buck, D.C. (2006-2007). Reflections on the Psycho-Spiritual Journey and the Self: in the Light of Christ. Sufi: A Journal of Sufism, (72), pp. 10-19.

Chittick, W.C. (2000). Sufism: a short introduction. Oxford: Oneworld Publications.

Chodkiewicz, M. , ed. (2002). The Meccan revelations (Futuhat al-Makiyya). New York: Pir

Press.

Cragg, K. (1985). Jesus and the Muslim: an exploration. London: Allen \& Unwin.

Davis, D. , trans. (1984). The conference of the birds. London: Penguin.

Dawood, N.J. , trans. (2003). The Koran. 5th ed. London: Penguin.

Ferguson, R.J. (1996). Meeting on the road: cosmopolitan Islamic culture and the politics of

Sufism (Research paper series: Centre for East-West Cultural \& Economic Studies, no. 4). Gold

Coast, QLD: Bond University, School of Humanities and Social Sciences, 34 pp.

Forouzanfar, B.A. , ed. (c. 2002). Koliyat-e Shams-e Tabrizi. Tehran: Talayeh.

Gorman, M. (2007). Jesus the Sufi: the lost dimension of Christianity. Bath: The Lantern Press and Crucible Publishers.

Heck, P.L. (2007). Sufism and politics: the power of spirituality. Princeton, NJ: Markus Wiener Publishers.

Howell, J. (2001). Sufism and the Indonesian Islamic Revival. Journal of Asian Studies, 60(3), pp. 701-729.

Khalidi, T. (2001). The Muslim Jesus: sayings and stories in Islamic literature. Cambridge, MA: Harvard University Press.

King, J.R. (1990). Jesus and Joseph in Rumi's Mathanwi. Muslim World, 80(2), pp. 81-95.

Lawson, T. (2009). The crucifixion and the Qur'an. Oxford: Oneworld Publications.

Leirvik, O. (2010). Images of Jesus Christ in Islam. London: Continuum.

Lewisohn, L. (1999). In quest of annihilation: imaginalization and mystical death in the Tamhidat of Ayn al-Qudat Hamadhani. In: L. Lewisohn, ed., The heritage of Sufism 1. Oxford: Oneworld Publications, pp. 285-336.

Lewisohn, L. (2001). The esoteric Christianity of Islam. In: L. Ridgeon, ed., Islamic interpretations of Christianity. New York: St. Martin's Press, pp. 127-156.

McConnell, W.J. (1988). The Qur'anic depiction of Jesus. Wheaton, IL: Evangelical Theological Society.

Malik, J. , and Hinnells, J. , eds. (2006). Sufism in the West. London: Routledge.

Mason, H. (1999). Hallaj and the Baghdad school of Sufism. In: L. Lewisohn, ed., The heritage of Sufism 1. Oxford: Oneworld Publications, pp. 65-82.

Massignon, L. , ed. (1974). Tawasin. A.A. al-Tarjumana, trans. Berkeley, CA: Diwan Press.

Massignon, L. (1994). The passion of Al-Hallaj: mystic and martyr of Islam. H. Mason , ed., trans. Princeton, NJ: Princeton University Press. 
Milani, M. (2012a). Representations of Jesus in Islamic Mysticism: Defining the 'Sufi Jesus'. Literature and Aesthetics, 21(2), pp. 45-64.

Milani, M. (2012b). The cultural products of global Sufism. In: C. Cusack and A. Norman , eds., Handbook of new religions and cultural production. 1st ed. Leiden: Brill, pp. 659-680.

Milani, M. (2012c). The cultural repository of Persian Sufism: medieval chivalry and mysticism in Iran. In: S. Hathaway and D. Kim , eds., Intercultural exchange in the early medieval Mediterranean. 1st ed. London: Continuum, pp. 63-83.

Milani, M. (2014). Sufism in the secret history of Persia. London: Routledge.

Mojaddedi, J. (2001). The biographical tradition in Sufism: the tabaqaat genre from al-Sulamii to Jami. Richmond, Surrey: Curzon Press.

Mourad, S.A. (1996). A Twelfth-Century Muslim Biography of Jesus. Islam and Christian-Muslim Relations, 7(1), pp. 39-45.

Nicholson, R.A. (1940). Commentary on Books 1 and 2 of The Mathnawi. Cambridge:

Cambridge University Press.

Nicholson, R.A. , ed. (1976). Kashf al-Mahjub (The revelation of the veiled). London: Luzac.

Nicholson, R.A. , ed. and trans. (1982). The Mathnawi of Jalaluddin Rumi: translations of Books III and IV. Cambridge: Cambridge University Press.

Nicholson, R.A. (1989). The mystics of Islam. London: Penguin Arkana.

Nicholson, R.A. (1994). Studies in Islamic mysticism. Cambridge: Cambridge University Press.

Nurbakhsh, J. (1992). Jesus in the eyes of the Sufis. 2nd ed. London: Khaniqahi Nimatullahi

Publications.

Nurbakhsh, J. (1996). Discourses on the Sufi path. London: Khaniqahi Nimatullahi Publications. Renard, J. (1987). Jesus and the Other Gospel Figures in the Writings of Jalal al-din Rumi. Hamdard Islamicus, 10(2), pp. 47-64.

Ridgeon, L. (2001). Christianity as portrayed by Jalal al-Din Rūmi. In: L. Ridgeon , ed., Islamic interpretations of Christianity. Abingdon: Routledge, pp. 99-126.

Robinson, N. (n.d.). Jesus. In: Encyclopaedia of the Qur'an. [Online] Available at: http://dx.doi.org.ezproxy.uws.edu.au/10.1163/1875-3922_q3_EQCOM_00099 [Accessed 2 Mar 2014 ].

Safi, O. (2006). The politics of knowledge in premodern Islam: negotiating ideology and religious inquiry. Chapel Hill, NC: University of North Carolina Press.

Salmasizadeh, J. (2003). Tadhkerat al-Auliya': Sheikh Farid al-Din Attar Neyshaburi. Tehran.

Sarrio, D.R. (2011). Spiritual Anti-Elitism: Ibn Taymiyya's Doctrine of Sainthood (Walaya). Islam and Christian-Muslim Relations, 22(3), pp. 275-291.

Schimmel, A. (1978). The triumphal sun. London: Fine Books Centre.

Sedgwick, M. (2012). Neo-Sufism. In: O. Hammer and M. Rothstein , eds., The Cambridge companion to new religious movements. Cambridge: Cambridge University Press, pp. 198-214. Shaki, M. , and Algar, H. (1996). Darvis. In: Encyclopaedia Iranica. Vol. 7. Santa Ana, CA: Mazda Publishers, pp. 72-76.

Singh, D.E. (2008). Comparing Revelatory Utterances in Charismatic Christianity and Islam. Journal of Beliefs and Values: Studies in Religion and Education, 29(1), pp. 61-73.

Soroudi, S.S. (1979). On Jesus's Image in Modern Persian Poetry. Muslim World, 69(4), pp. 221-228.

Stork, M. (2002). A-Z guide to the Qur'an. Singapore: Marshall Cavendish Editions. Trimingham, J.S. (1998). The Sufi orders in Islam. Oxford: Oxford University Press. Urubshurow, V.K. (1997). Hierophanic History and the Symbolic Process: A Response to Ricoeur's Call for a 'Generative Poetics'. Studies in Spirituality, 7, pp. 263-291.

Vernon, M. (2009). Chambers dictionary of beliefs and religions. Edinburgh: Chambers. Woodberry, J.D. , Shubin, R.G. , and Marks, G. (2007). Why Muslims Follow Jesus. Christianity Today. [Online] Available at: www.liebenzell.org/fileadmin/user_upload/seminar/downloads/WoodberrySurvey_Christianity_T oday.pdf [Accessed 1 Jun 2014 ]. 


\section{Sufi politics in contemporary global society}

1

Ahmed, S. (2016). What is Islam? The importance of being Islamic. Oxford: Princeton University Press.

Bruinessen, M. (2009). Sufism, "popular" Islam and the encounter with modernity. In: M.K.

Masud, A. Salvatore and M. van Bruinessen, eds., Islam and modernity. Edinburgh: Edinburgh University Press, pp. 125-157.

Bulliet, R. (1994). Islam: the view from the edge. New York: Columbia University Press.

Calder, N. , Mojaddedi, J. , and Rippin, A. (2003). Classical Islam: a sourcebook of religious literature. London: Routledge.

Chih, R. (2000). Le Sufism au quotidien: confréries d'Egypte au Axe siècle. Paris: Sindbad.

Drage, T. (2012). The National Sufi Council: redefining the Islamic Republic of Pakistan through a discourse on Sufism after 9/11. PhD. Western Sydney University.

Forum . (2007). [Online] Available at:

https://groups.google.com/forum/\#!msg/alt.sufi/LduKU6y_DWY/LZ-jY34974w] [Accessed 5 Apr 2009 ].

Geertz, C. (1968). Islam observed: religious development in Morocco and Indonesia. New

Haven, CT: Yale University Press.

Gellner, E. (1981). Muslim society. Cambridge: Cambridge University Press.

Gilsenan, M. (1967). Some Factors in the Decline of Sufi Orders in Modern Egypt. Muslim World, 57(1), pp. 11-18.

Gilsenan, M. (1982). Recognising Islam: religion and society in the modern Arab world. New York: Pantheon Books.

Goodman, L.E. (2003). Islamic humanism. Oxford: Oxford University Press.

Graham, T. (1999a). Shah Ni'matullah Wali: founder of the Nimatullahi Sufi order. In: L.

Lewisohn, ed., The heritage of Sufism (Vol. 2). Oxford: Oneworld Publications, pp. 173-190.

Graham, T. (1999b). The Ni'matu'llahi order under Safavid suppression and in Indian exile. In:

L. Lewisohn, ed., The heritage of Sufism (Vol. 3). Oxford: Oneworld Publications, pp. 165-200.

Hartman, R. (1916). Zur frage nach der herkunft und den anfängen des Sufitums. (Vol. 6). Der

Islam Berlin, pp. 31-70.

Heelas, P. (2011). Third force Sufism. In: International Conference: Sufism for a New Age:

Twenty-first Century Neo-Sufism. Cosmopolitan Piety and Traditionalist Responses, Western

Sydney University (unpublished).

Henkel, H. (2009). One foot rooted in Islam, the other foot circling the world. In: C. Raudvere and L. Stenberg , eds., Sufism today: heritage and tradition in the global community. London:

I.B. Tauris, pp. 103-116.

Hermansen, M. (2006). Literary production of western Sufi movements. In: J. Malik and J.

Hinnells, eds., Sufism in the West. Abingdon: Routledge, pp. 28-48.

Hoffman, V.J. (1995). Sufism, mystics, and saints in modern Egypt. Columbia, SC: University of South Carolina Press.

Johansen, J. (1996). Sufism and Islamic reform in Egypt: the battle for Islamic tradition. Oxford: Clarendon Press.

Lewisohn, L. (2006). Persian Sufism in the contemporary west: reflections on the Nimatullahi Diaspora. In: J. Malik and J. Hinnells, eds., Sufism in the West. Abingdon: Routledge, pp. 49-70.

Malik, J. , and Hinnells, J. , eds. (2006). Sufism in the West. Abingdon: Routledge.

Milani, M. (2012). Medieval Persian chivalry and mysticism. In: S. Hathaway and D. Kim , eds., Intercultural transmission in the medieval Mediterranean. London: Continuum.

Milani, M. (2014). Sufism in the secret history of Persia. Abingdon: Routledge.

Milani, M. (2015). Sufism and the challenge of modernity in the twenty-first century. In: M.H. Faghfoory and G. Dastagir , eds., Sufism and social integration: connecting hearts, crossing boundaries. Chicago, IL: ABC International Group, pp. 367-384.

Milani, M. (2017). Sufi politics in the contemporary west: the role and definition of Sufism in the works of Javad Nurbakhsh (1926-2008). In: C. Bennett and S. Alam, eds., Sufism, pluralism and democracy. London: Equinox Publishing.

Milani, M. , and Possamai, A. (2016). Sufism, Spirituality and Consumerism: The Case Study of the Nimatullahiya and Naqshbandiya Sufi Orders in Australia. Contemporary Islam: Dynamics of 
Muslim Life, 10(1), pp. 67-85.

Nawruziyan, P. (1997a). Taj-i Kay Khusraw bar sar-i Shaykh Ishraq I. Sufi, 34, pp. 26-31.

Nawruziyan, P. (1997b). Taj-i Kay Khusraw bar sar-i Shaykh Ishraq II. Sufi, 35, pp. 26-34.

Nawruziyan, P. (2000). Zartusht u hukamayi bastani-yi Iran. Sufi, 49, pp. 12-18.

Nurbakhsh, J. (1980). Divan-e Nurbakhsh: Sufi poetry. London: Khaniqahi Nimatullahi

Publications.

Nurbakhsh, J. (1992). The psychology of Sufism. London: Khaniqahi Nimatullahi Publications. Nurbakhsh, J. (1996). Discourses on the Sufi path. London: Khaniqahi Nimatullahi Publications.

Pourjavady, N. , and Wilson, P.L. (1978). The kings of love: the poetry and history of the Nimatullahi Sufi order. Tehran: Imperial Iranian Academy of Philosophy.

Quinn, S.A. (1999). Rewriting Nimatullahi history in Safavid chronicles. In: L. Lewisohn, ed., The heritage of Sūfism (Vol. 3). Oxford: Oneworld Publications, pp. 201-222.

Ridgeon, L. (2011). Sufi castigator: Ahmad Kasravi and the Iranian mystical tradition. Abingdon: Routledge.

Smith, L. (2008a). Interview with Dr Javad Nurbakhsh (Part 1). [Online] Available at: www.nimatullahi.org/media-library/video/interview-with-dr-javad-nurbakhsh-part-1.php [Accessed 1 Feb 2013].

Smith, L. (2008b). Interview with Dr Javad Nurbakhsh (Part 2). [Online] Available at: www .nimatullahi.org/media-library/video/interview-with-dr-javad-nurbakhsh-part-2.php [Accessed 1 Feb 2013 ].

Spellman, K. (2004). Religion and nation: Iranian local and transnational networks in Britain. New York: Berghahn.

Trimingham, J.S. (1998). The Sufi orders in Islam. Oxford: Oxford University Press.

Van den Bos , M. (2002). Mystic regimes: Sufism and the state in Iran, from the late Qajar era to the Islamic Republic. Leiden: Brill.

Zarrinkub, A.H. (1978). Justuju dar tasawwuf-i Iran. Tehran.

Zubaida, S. (1993). Islam, the people and the state: political ideas and movements in the Middle East. London: I.B. Tauris.

\section{The subtle body and the experience of politics in the human \\ 1}

Baba, M. (1973). God speaks: the theme of creation and its purpose. New York: Dodd, Mead. Bourdieu, P. (1984). Distinction. London: Routledge.

Bourdieu, P. (1991). Language and symbolic power. J.B. Thompson, ed. Cambridge: Polity Press.

Böwering, G. (1980). The mystical vision of existence in classical Islam: The Qur'anic hermeneutics of the Sufi Sahl at-Tustari (d. 283/896). New York: Walter De Gruyter.

Buehler, A.F. (1998). Sufi heirs of the prophet: the Indian Naqshbandiyya and the rise of the Sufi shaykh. Columbia, SC: University of South Carolina Press.

Colby, F.S. (2006). The subtleties of ascension. Louisville, KY: Fons Vitae.

Colby, F.S. (2008). Narrating Muhammad's night journey: tracing the development of the Ibn Abbas ascension discourse. Albany, NY: Suni Press.

Corbin, H. (1971). En Islam Iranien (4 vols.). Paris: Editions Gallimard.

Corbin, H. (1978). The man of light in Iranian Sufism. London: Shambhala.

Corbin, H. (1993). History of Islamic philosophy. London: Kegan Paul.

Dale, C. (2009). The subtle body: an encyclopedia of your energetic anatomy. Boulder, CO:

Sounds True.

Davis, D. , trans. (1984). The conference of the birds. London: Penguin.

Déclais, J.L. (2010). Names of the prophet. In: Encyclopaedia of the Qur'an, 3, s.v. [Online] Available at: http://dx.doi.org.ezproxy.uws.edu.au/10.1163/1875-3922_q3_EQCOM_00130 [Accessed 27 Jun 2017 ].

Frager, R. (1999). Heart, self \& soul: the Sufi psychology of growth, balance, and harmony. Wheaton, IL: Quest Books. 
Geaves, R. (2006). Learning the lessons from the neo-revivalist and Wahhabi moevements: the counterattack of the new Sufi movements. In: J. Malik and J. Hinnells, eds., Sufism in the West. London: Routledge, pp. 142-159.

Guillaume, A. (1955). The life of Muhammad: a translation of Ibn Ishaq's sirat rasul allah. Oxford: Oxford University Press.

Hermansen, M.K. (1988). Shah Wali Allah's Theory of the Subtle Spiritual Centers (Lataif): A Sufi Model of Personhood and Self-Transformation. Journal of Near Eastern Studies, 47, pp. 1-25.

Howell, J.D. and Bruinessen, M. (2007). Sufism and the 'modern' in Islam. London: I.B. Tauris. Kamada, S. (2010). Secrets. In: Encyclopaedia of the Qur'an, 4, s.v. [Online] Available at: http://dx.doi.org.ezproxy.uws.edu.au/10.1163/1875-3922_q3_EQSIM_00378 [Accessed 27 Jun 2017 ].

Khan, I. (1914). Sufi message of spiritual liberty. London: The Theosophical Publishing Society. Lewisohn, L. (2006). Persian Sufism in the contemporary West: reflections on the Ni'matu'llahi diaspora. In: J. Malik and J. Hinnells, eds., Sufism in the West. London: Routledge.

Massignon, L. (1982). The passion of Hallaj: mystic and martyr of Islam (4 vols.). H. Mason , trans. Princeton, NJ: Princeton University Press.

Milani, M. (2013). The subtle body in Sufism. In: G. Samuel and J. Johnston, eds., Religion and the subtle body in Asia and the West: between mind and body. London: Routledge.

Milani, M. (2014). Sufism in the secret history of Persia. London: Routledge.

Mojaddedi, J. (2001). The biographical tradition in Sufism: The Tabaqat genre from al-Sulami to Jami. London: Curzon Press Publishers.

Mojaddedi, J. , trans. (2003). The Masnavi: book one. Oxford: Oxford University Press.

Nicholson, R.A. , ed. (1976). Kashf al-Mahjub (The revelation of the veiled). London: Luzac.

Nicholson, R.A. , ed. and trans. (1982). The Mathnawi of Jalaluddin Rumi: translations of Books I and II. Cambridge: Cambridge University Press.

Nicholson, R.A. (1994). Studies in Islamic mysticism. Cambridge: Cambridge University Press. Nurbakhsh, J. (1980). Masters of the path. New York: Khaniqahi Nimatullahi Publications. Nurbakhsh, J. (1991). irfan va ravaan-shenaasi mawlana: dar daasstaneh paadeshah va kanizak. Sufi, 8, pp. 7-10.

Nurbakhsh, J. (1993). The psychology of Sufism. London: Khaniqahi Nimatullahi Publications. Nurbakhsh, J. (1996). Discourses. London: Khaniqahi Nimatullahi Publications.

Plato . (2003). The republic. London: Penguin.

Purdom, C.B. (1964). The god-man: the life, journeys \& work of Meher Baba with an interpretation of his silence \& spiritual teaching. London: Allen \& Unwin.

Purjavadi, N. (1979). Sultan-i tariqat: sawanih zindagi wa-sharh-i athar-i Khwaja Ahmad

Ghazzali. Tehran: Intisharat-i Agah.

Qushayri . (1959). al-Risâla al-qushayriya. Cairo.

Rahman, F. (2010). Baka wa-Fana. In: Encyclopaedia of Islam. 2nd ed. [Online] Available at: http://dx.doi.org.ezproxy.uws.edu.au/10.1163/1573-3912_islam_SIM_1083 [Accessed 27 Jun 2017 ].

Raudvere, C. , and Stenberg, L. , eds. (2009). Sufism today: heritage and tradition in the global community, London: I.B. Tauris.

Ridgeon, L. (2010). Morals and mysticism in Persian Sufism. New York: Routledge.

Safavi, S.G. (2005). Synoptic Approach to Story of the King and the Handmaiden of Book One of the Mathnawi of Rumi. Transcendental Philosophy: An International Journal for Comparative Philosophy and Mysticism, 6(1a2), pp. 37-50.

Schimmel, A. (1985). And Muhammad is his messenger: the veneration of the Prophet in Islamic piety. Chapel Hill, NC: University of North Carolina Press.

Schrieke, B. , Horovitz, J. , Bencheikh, J.E. , Knappert, J. , and Robinson, B.W. (2010). Mi rādj. In: Encyclopaedia of Islam. 2nd ed. [Online] Available at: http://dx.doi.org .ezproxy.uws.edu.au/10.1163/1573-3912_islam_COM_0746 [Accessed 27 Jun 2017 ].

Sedgwick, M. (2005). Neo-Sufism. In: W. J. Hanegraaff, ed., Dictionary of western esotericism and gnosis (Vol. 2). Leiden: Brill, pp. 846-849.

Shikarpuri, F. (1978). Qutb al-irshad. Quetta: Maktaba-yi Islamiyya.

Shikarpuri, F. (n.d.). Maktubat-i Faqirullah. Maulwi Karam Bakhsh, ed. Lahore: Islamiyya Steam Press. 
Silvers, L. (2010). A soaring minaret: Abu Bakr al-wasiti and the rise of Baghdadi Sufism. Albany, NY: State University of New York Press.

Smith, M. (1978). The way of the mystics. New York: Oxford University Press.

Suhrawardi, S. ([1945] 1993). Opera metaphysica et mystica I. H. Corbin , ed. and intro. Tehran: Mu'assasah-yi Mutali'at va Tahqiqat-i Farhangi.

Westerlund, D. (2004). Sufism in Europe and North America. Abingdon: Routledge.

Whitcomb, B. (1993). The magician's companion: a practical and encyclopedic guide to magical and religious symbolism. St Paul, MN: Llewellyn Publications. 